\title{
Record of insect pollinators on the inflorescence of Murraya koenigii in Rajasthan
}

\author{
S Bhatnagar, LS Rathore, G Vishnoi, AU Khan \& B Kumar
}

Journal of Agriculture and Ecology

ISSN: 2456-9410

Volume: 5

Journal of Agriculture and Ecology (2018) 5: 38-41 http://doi.org/10.53911/JAE.2018.5103 
Record of insect pollinators on the inflorescence of Murraya koenigii in Rajasthan

S Bhatnagar \\, LS Rathore, G Vishnoi, AU Khan \& B Kumar

Forest Protection Division, Arid Forest Research Institute, Jodhpur

Corresponding author: S Bhatnagar, E-mail: shiwani.bhatnagar@gmail.com

\section{Article Info}

Article history

Received: 25 January 2018

Accepted: 20 May 2018

Available online: 15 June

2018

Key Words: Murraya

Koenigii, pollinators.

\begin{abstract}
Observations were recorded on the insect pollinators visiting the blossom of Murraya Koenigii in April-May. Flowers are white, funnel shaped with terminal cymes. Flower serves as nectar and pollen resource for the insect pollinators. Three species of order Lepidoptera and five species of order hymenoptera were recorded during the present study.
\end{abstract}

Copyright (C2018 Bhatnagar et al., This is an open access article published under the terms of the Creative Commons Attribution License, which permits unrestricted use, distribution, and reproduction in any medium, provided the original work is properly cited.

Preferred citation: Bhatnagar S, Rathore LS, Vishnoi G, Khan AU \& Kumar B. 2018. Record of insect pollinators on the inflorescence of Murraya koenigii in Rajasthan. Journal of Agriculture and Ecology, 5: 38-41; http://doi.org/10.53911/JAE.2018.5103.

\section{Introduction}

Murraya Koenigii (curry-leaf tree), belongs to the family Rutaceae and is a native of India, Sri Lanka and other south Asian countries. It is aromatic in nature, more or less deciduous shrub or tree reaching up to a height of $6 \mathrm{~m}$ and $15-40 \mathrm{~cm}$ in diameter (Mhaskar et al., 2000). Its flowering season is April-May and flowers are bisexual, white, funnel shaped, stalked, complete, ebracteate, regular with terminal cymes each bearing around 60-90 flowers (Prajapati et al. 2003).

\section{Taxonomy details of the tree}

Kingdom: Plantae

Division: Magnoliophyta

Class: Magnoliospida

Order: Sapindales

Family: Rutaceae
Genus: Murraya

Species: Murraya Koenigii L. Spreng.

M. koenigii has various important uses in the traditional system of medicine in Eastern Asia (Ningappa and Srinivas, 2008). It is used as a stimulant, antidysentric and for the management of Diabetes mellitus (Xie et al. 2006). The plant is highly valued for its leaves as an important ingredient in an Indian cuisine to promote appetite and digestion. The leaves, root and bark are tonic, stomachic and carminative. Leaf extracts of Murraya Koenigii have been screened for some pharmacological uses and found to possess anti-diabetic, cholesterol reducing property, anti-diarrhea activity, cytotoxic activity antioxidant property, antiulcer activity antimicrobial, antibacterial potential and many 
more useful medicinal properties (Handral et al. 2012).

Pollinators viz., bees, butterflies, moths are an integral part of our environment and have important role in (35\%) global crop production and sustain diverse wildlife categories (Mangowi 2014) and directly affect the timing, amount and quality of pollen deposited and ultimately, plant population dynamics (Hargreaves et al. 2009; Kunin 1993; Cussans et al. 2010; Flanagan et al. 2011; Jha \& Dick 2010; Chalcoff et al. 2012, Singh et al. 2016). Therefore, it is important to know the pollinators of medicinally important plants/tree species. With this view present study was conducted to record the insect pollinators of Murraya koenigii.

\section{Material and Methods}

Observation on the insect pollinators visiting the inflorescence of $M$. koenigii was recorded during the peak flowering season. These observations were recorded from 6:00 am to 6:00 pm at an interval of 3:00 hours. Observations were recorded after the initiation of $10 \%$ flowering and abundance of major pollinators (number of visitors/ cymes/5 minutes) was recorded. Insect visitors either visited the flowers or for the nectar or pollen rewards.

\section{Result and Discussion}

The peak flowering period in Murraya koenigii was observed to be the last week of April. The number of species and abundance of insects visiting the flowers changed throughout the day and was observed lowest in the morning (06:00-09:00 hrs), and highest between 9:00-12:00 hrs of the day. The visits were low at the time of commencement and cessation of flowering period but these remained high during mid flowering period. The difference may be due to variation in the floral density during the span of blooming of tree (Table 1). Similar findings were reported by Kendell \& Smith (1975); Willson \& Price (1977); Schaffer \& Schaffer (1979); Schemske (1980); Dhaliwal \& Atwal (1985) who stated that at the peak flowering, number of flowers was more/maximum and these were visited by larger number of pollinators.

Insect visitors visiting the blossom of Murraya koenigii were collected and identified. Three species of Apidae family, two species of Vespidae and three species of Papilionidae family were observed during the period. Apis florea were recorded as top visitors on inflorescence of Murraya koenigii as pollen and nectar gatherers followed by Apis dorsata. Of all the insect visitors, $A$. dorsata and A. mellifera were the most abundant visitors. Xylocopa was found to be the least abundant among order Hymenoptera. Papilio polytes was observed most abundant among lepidopteran insects (Table 2). 


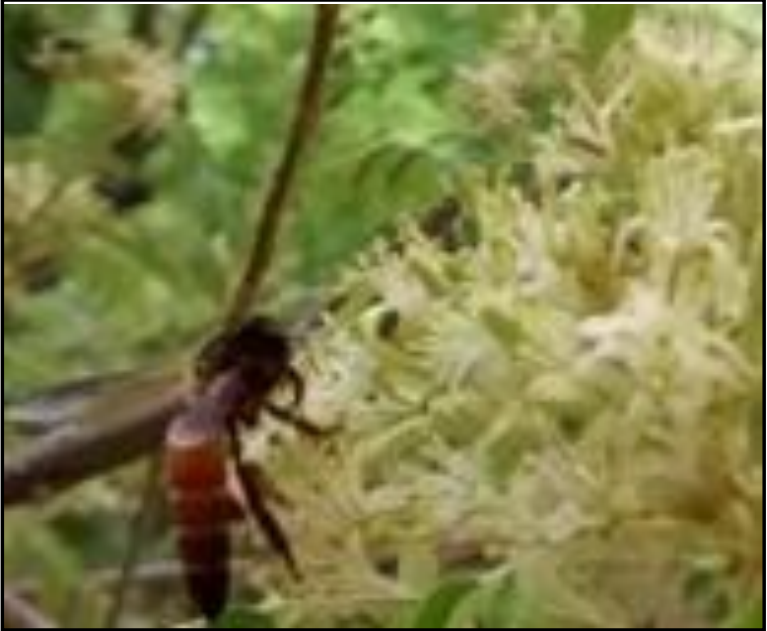

Apis dorsata

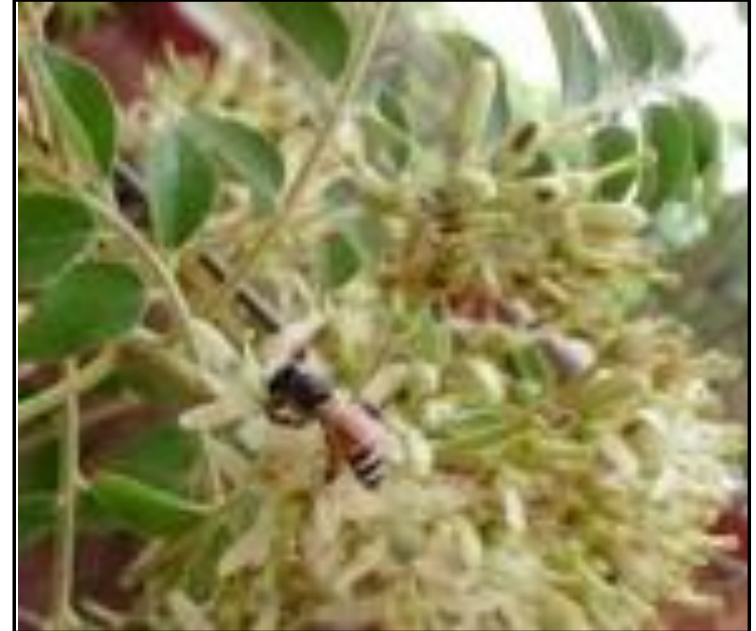

Apis florea

Table 1. Pollination time of insect pollinators on the inflorescence of Murraya koenigii in Rajasthan

\begin{tabular}{lccccc}
\hline Insect species & \multicolumn{5}{c}{ Number of pollinators/ cymes / 5 minutes during different day } \\
& $6.00-9.00$ & $9.00-12.00$ & $12.00-3.00$ & $3.00-6.00$ & Mean \\
\hline Pachliopta aristolochiae & 1.00 & 1.67 & 1.33 & 1.33 & 1.332 \\
Papilio demoleus & 1.00 & 1.33 & 2.00 & 1.33 & 1.415 \\
Papilio polytes & 1.33 & 2.00 & 1.33 & 1.67 & 1.583 \\
Vespa orientalis & 0.00 & 1.67 & 1.00 & 1.67 & 1.085 \\
Polistes hebraeus & 0.00 & 2.00 & 1.67 & 1.67 & 1.335 \\
Apis florea & 2.66 & 5.67 & 4.33 & 5.00 & 4.415 \\
Apis dorsata & 2.00 & 3.33 & 2.67 & 3.00 & 2.750 \\
Xylocopa fenestrata & 0.00 & 1.67 & 1.67 & 1.33 & 1.168 \\
\hline
\end{tabular}

Table 2. List of insect pollinators on the inflorescence of Murraya koenigii in Rajasthan

\begin{tabular}{llll}
\hline \multicolumn{1}{c}{ Common Name } & Scientific Name & Order & Family \\
\hline Common rose & Pachliopta aristolochiae & Lepidoptera & Papilionidae \\
Lemon butterfly & Papilio demoleus & Lepidoptera & Papilionidae \\
Common Mormon & Papilio polytes & Lepidoptera & Papilionidae \\
Oriental hornet & Vespa orientalis & Hymenoptera & Vespidae \\
Paper wasp & Polistes hebraeus & Hymenoptera & Vespidae \\
Little bee & Apis florea & Hymenoptera & Apidae \\
Giant bee & Apis dorsata & Hymenoptera & Apidae \\
Carpenter bee & Xylocopa fenestrata & Hymenoptera & Apidae \\
\hline
\end{tabular}




\section{References}

Chalcoff VR, Aizen MA \& Ezcurra C. 2012. Erosion of a pollination mutualism along an environmental gradient in a south Andean treelet, Embothrium coccineum (Proteaceae). Oikos, 121: 471-480.

Cussans J, Goulson D, Sanderson R, Goffe L, Darvill B \& Osborne JL. 2010. Two beepollinated plant species show higher seed production when grown in gardens compared to arable farmland. PLoS One, 5(7): e11753.

Dhaliwal JS \& Atwal AS. 1985. Effect of age of crop, plant spacing, soil moisture and phosphatic fertilizers on bee activity on Brassica crop. In Pollination Biology: An Analysis. (ed. Kapil, R.P.). Inter India Publication. 91-101.

Flanagan RJ, Mitchell RJ \& Karron JD. 2011. Effects of multiple competitors for pollination on bumblebee foraging patterns and Mimulus ringens reproductive success. Oikos, 120:200-207.

Handral HK, Pandith A \& Shruthi SD. 2012. A review on Murraya koenigii: multipotential medicinal plant. Asian journal of pharmaceutical and clinical research, 5 (4): 5-14.

Hargreaves AL, Harder LD \& Johnson SD. 2009. Consumptive emasculation: the ecological and evolutionary consequences of pollen theft. Biological Review, 84: 259-276.

Jha S \& Dick CW. 2010. Native bees mediate long-distance pollen dispersal in a shade coffee landscape mosaic. Proceedings of National Academy of Science, USA, 107: 13760-13764.

Kendell DA \& Smith BD. 1975. The forging behaviour of honeybee on ornamental Malus spp. used as pollinizers in apple orchards. Journal of Applied Ecology, 12: 465-471.
Kunin WE. 1993. Sex and the single mustard: population density and pollinator behavior effects on seed-set. Ecology, 74: 21452160.

Mangowi AL. 2014. Effect of agriculture on abundance and diversity of arthropods with chewing mouth parts at Sokoine University of Agriculture Main Campus. Journal of Natural Sciences Research, 4(4): 55-62.

Mhaskar KS, Blatter E, Caius JF, Kirtikar \& Basu. 2000. Illustrated Indian Medicinal Plants Vol. I. XI. 3rd Edn. Indian Medical Science Series, Delhi, India. 86-96.

Ningappa MB \& Srinivas L. 2008. Toxicology in Vitro, 22: 699-709.

Prajapati ND, Purohit SS, Sharma AK \& Kumar T. 2003. A book of Medicinal plants, 1st ed., Agrobios, India.

Schaffer WM \& Schaffer MV. 1979. The adaptive significance of variations in reproductive habit in the Aguacate II: Pollinator foraging behaviour and selection for increased reproductive expenditure. Ecology, 60: 1051-1069.

Schemske DW. 1980. Floral ecology and humming bird pollination of Combretum farinosum in Coste Rice. Bitropica, 12: 169-171.

Singh H, Swaminathan R \& Haldhar SM. 2016. Foraging behavior of insect pollinators on coriander. Indian Journal of Arid Horticulture, 11: 74-80.

Willson M \& Price PW. 1977. The evolution of inflorescence size in Asclepias (Asclepiadaceae). Tropical Agriculture, 54: 353-356.

Xie JT, Chang WT, Wang CZ, Mehendale SR., Li J \& Ambihaipahar R . 2006. Curry leaf Murraya koenigii Spreng. reduces blood cholesterol and glucose levels in ob/ob mice. The American Journal of Chinese Medicine, 34: 279-284. 